\title{
Plasma sex hormone concentrations during the reproductive cycle in the male lizard, Podarcis $s$. sicula
}

\author{
S. Andò, M. L. Panno, G. Ciarcia*, E. Imbrogno, M. Buffone, E. Beraldi†, \\ D. Sisci, F. Angelini* and V. Botteł
}

Dipartimento di biologia cellulare Università della Calabria, Arcavacata di Rende-Cosenza, Italy;

* Dipartimento di biologia evolutive e comparata Università di Napoli, Naples, Italy; $†$ Istituto per lo studio delle malattie ereditarie e carenziali, CNR (CS), Italy; $\ddagger$ Dipartimento di Zoologia, Università di Napoli, Naples, Italy

\begin{abstract}
Summary. Progesterone, 17-hydroxyprogesterone, androstenedione, $5 \alpha$-dihydrotestosterone, dehydroepiandrosterone, testosterone and oestradiol concentrations in the plasma were measured by simultaneous radioimmunoassay in males of the lizard Podarcis s. sicula. Hormonal determinations were performed at monthly intervals from January to December (except for August). Testosterone and androstenedione reached peak values of $174.8 \mathrm{ng} / \mathrm{ml}$ and $21.4 \mathrm{ng} / \mathrm{ml}$ in the mating season (spring) and then testosterone fell abruptly to $5.9 \mathrm{ng} / \mathrm{ml}$ in June remaining at this level during hibernation when dehydroepiandrosterone (DHA) reached a maximal level of $28.5 \pm 9.3 \mathrm{ng} / \mathrm{ml}$. Castration resulted in a marked decrease of testosterone, androstenedione, dihydrotestosterone and DHA values, with DHA being significantly lowered only during the winter season. In castrated animals, however, testosterone and androstenedione persisted conspicuously in the plasma during the breeding period, suggesting that adrenal sex steroid output may change during the annual reproductive cycle. In intact animals, progesterone and oestradiol exhibited peak values during the refractory period after the mating season. We suggest a probable role of oestradiol in the induction of the refractory period in this lizard.
\end{abstract}

Kev'words: sex steroids; sexual cycle; lizards; androgens; oestrogens

\section{Introduction}

Reproduction of most reptilian species occurs in the more favourable period of the year, usually spring, when gonads undergo development and secondary sexual characters develop (Angelini \& Ghiara, 1984; Licht, 1984; Lofts, 1987). Seasonal changes in the concentrations of circulating sex hormones have been reported for several species of reptiles (Tam et al., 1969; Callard et al., 1976; Arslan et al., 1978; Bourne \& Seamark, 1978; Courty \& Dufaure, 1979; Bona Gallo et al., 1980; Mahmoud et al., 1985; Bradshaw et al., 1988). These changes parallel those in size and histology of the testis and accessory sexual organs. In Podarcis s. sicula, a lizard inhabiting northern temperate zones, a sexual annual cycle has been reported which is characterized by the following phases. (1) In the middle of March, after emergence from winter shelters, there is a marked reactivation of spermatogenesis with intense spermiation (prenuptial type) coupled to development of secondary sexual characters. Mating occurs in spring. (2) In late June, when mean temperature is still favourable, a refractory period occurs, inducing a complete block of spermatogenesis, and the regression of secondary sexual characters. (3) In September, a decrease in the intensity of the refractoriness allows partial revival of spermatogenesis, but not spermiation. Secondary sexual characters do not develop. (4) In late November until February, spermatogenesis ceases since the mean 
environmental temperature has become too cold and the lizards semi-hibernate (Angelini et al., 1976, 1986; Arslan et al., 1978; Angelini \& Ghiara, 1984). Changes in plasma sex hormone values have been only partly investigated for male Podarcis s. sicula (Angelini et al., 1986; Ciarcia et al., 1986), and data concerning the correlation between circulating concentrations of sex steroids and reproductive activity are still lacking. In the present study monthly determinations were made during the annual cycle of the plasma concentrations of several steroids, and castrated lizards were also studied to evaluate the contribution of adrenal androgen secretions (Rivarola et al., 1968; Chester Jones, 1987; Kime, 1987).

\section{Materials and Methods}

Animals. The animals (see Table 1) were captured in the neighbourhood of Naples. Body weight ranged from 11 to $13 \mathrm{~g}$ and the mouth-vent length was $7-8 \mathrm{~cm}$. Blood was collected soon after capture, with a heparinized glass capillary inserted into the heart. The plasma obtained after centrifugation was preserved at $-70^{\circ} \mathrm{C}$ until use.

At autopsy, testes and epididymides were excised. The testes were weighed and the organs were then plunged into Stieve's fixative. Histological sections of the tissues, made by the usual techniques and stained with haematoxylineosin, were utilized to assess spermatogenic activity and epididymal development.

Gonadectomy was carried out on lizards (usually 20 for each group) caught in March, May and December. Control specimens were sham-operated. Mortality was very low. Operated lizards were maintained in terraria with a normal environmental temperature and photoperiod, and were fed ad libitum on meal worms and fresh vegetables. At 3 weeks after operation, the animals were killed and studied as reported above.

Combined RIA of testosterone and $5 \alpha$-dihydrotestosterone. Testosterone and $5 \alpha$-dihydrotestosterone were determined on the same plasma sample after ether extraction by an RIA method (Andò et al., 1988a), utilizing the antiserum antT-3-CMO-BSA (which cross-reacts $38.8 \%$ with $5 \alpha$-dihydrotestosterone, $6.4 \%$ with $5 \alpha$-androstane- $3 \alpha, 17 \beta$-diol, $1 \cdot 6 \%$ with androstenedione, $1.6 \%$ with $5 \alpha$-androstene- $3 \beta, 17 \beta$-diol and $\sim 0.01 \%$ with other steroids). The ether extract of $10 \mu \mathrm{l}$ plasma (in the animals captured during the January-June period), and $20 \mu \mathrm{l}$ plasma (for the animals captured during the July-December period) was submitted to paper chromatography at $22^{\circ} \mathrm{C}$ on Whatman No. 40 paper in the Bush A2 system, with reference labelled steroids on the side lines. The separation was required because the antiserum used cross-reacts about $40 \%$ with $5 \alpha$-dihydrotestosterone. The zones of migration corresponding to testosterone and $5 \alpha$-dihydrotestosterone were eluted with $5 \mathrm{ml}$ methanol. After evaporation of the eluate to dryness, the residue was dissolved in $500 \mu \mathrm{l}$ buffer for the testosterone assay $(200 \mu \mathrm{l}$ were taken for recovery evaluation and $100 \mu 1$ in duplicate for RIA) and $320 \mu \mathrm{l}$ buffer for the $5 \alpha$-dihydrotestosterone assay $(100 \mu \mathrm{l}$ were taken for recovery evaluation and $100 \mu \mathrm{l}$ in duplicate for RIA). Then $100 \mu \mathrm{l}$ of a 1:7000 diluted antiserum containing $22000 \mathrm{~d} . \mathrm{p} . \mathrm{m}$. of the corresponding $\mathrm{H}$ steroid were added to standards and unknowns, and, after standing overnight at $4^{\circ} \mathrm{C}$, the bound steroid was separated by Dextran-coated charcoal from the free fraction. The percentage recovery of labelled steroids added was $52 \cdot 0 \pm 2 \cdot 1 \%$ for testosterone and $55 \cdot 5 \pm 3 \cdot 2 \%$ for $5 \alpha$-dihydrotestosterone. The sensitivity was $10 \mathrm{pg} / \mathrm{tube}$ for both steroids. The water blank was $9 \mathrm{pg} /$ tube for testosterone and $8 \mathrm{pg} /$ tube for dihydrotestosterone. The intra- and inter-assay coefficients of variation were 9.3 and $12 \%$ for testosterone and 8 and $13 \%$ for $5 \alpha$-dihydrotestosterone, respectively.

Combined RIA of dehydroepiandrosterone and androstenedione. Dehydroepiandrosterone and androstenedione were determined in the same plasma sample after extraction by an RIA method (Andò et al., 1988a), utilizing a rabbit antiserum to DHEA-17-CMO-BSA (which cross-reacts about $7 \cdot 3 \%$ with $5 \alpha$-androstene-3 $\beta, 17 \beta$-diol, $4 \cdot 1 \%$ with pregnenolone, $0.1 \%$ with $17 \alpha$-hydroxypregnenolone and androstenedione, and $\sim 0.01 \%$ with other steroids) and a rabbit antiserum to A-11- $\alpha$-HS-BSA (which cross-reacts about $16 \cdot 4 \%$ with $5 \alpha$-androstenedione, $3 \cdot 7 \%$ with $5 \beta$ androstenedione, $0.3 \%$ with testosterone and $\sim 0.01 \%$ with other steroids). The diluted antiserum used was $1: 6000$ for dehydroepiandrosterone and 1:5000 for androstenedione. The ether extract of $10 \mu l$ (for the animals captured during the January-June period) and of $20 \mu \mathrm{l}$ (for the animals captured during the June-December period) was purified by paper chromatography at $22^{\circ} \mathrm{C}$ on Whatman No. 40 paper in a Bush A2 system with labelled reference steroids in the side lines. The zones of migration corresponding to dehydroepiandrosterone and androstenedione were eluted with $5 \mathrm{ml}$ methanol. After evaporation to dryness the residue was dissolved in $500 \mu \mathrm{l}$ for both steroids $(200 \mu \mathrm{l}$ were taken for recovery evaluation and $100 \mu \mathrm{l}$ in duplicate for RIA). The percentage recovery of the labelled steroids added was $50 \pm 3 \cdot 2 \%$ for dihydroepiandrosterone and $61.6 \pm 2 \%$ for androstenedione. The sensitivity was $15 \mathrm{pg} /$ tube for dehydroepiandrosterone and $10 \mathrm{pg} /$ tube for androstenedione. The water blank varied between 10 and $28 \mathrm{pg} / \mathrm{tube}$ for dehydroepiandrosterone and was $8 \pm 1 \cdot 1 \mathrm{pg} /$ tube for androstenedione. The intra-assay coefficients of variation for dehydroepiandrosterone and androstenedione were $11 \%$ and $8 \%$ respectively. The interassay coefficients of variation were respectively $13.8 \%$ and $12 \%$.

Combined RIA of progesterone and 17-hydroxyprogesterone. Progesterone and 17-hydroxyprogesterone were measured in the same plasma sample $(20 \mu \mathrm{l}$ and $40 \mu \mathrm{l}$ plasma, respectively). The plasma extract was chromatographed on a Sephadex LH-20 column, at room temperature, to separate the two steroids (Andò et al., 1984). The following 
antisera were respectively used for RIA determination: a rabbit antiserum to P-11- $\alpha-3-\mathrm{CMO}-\mathrm{BSA}$ (which cross-reacts about $55 \cdot 3 \%$ with $11 \alpha$-hydroxyprogesterone, $12 \cdot 2 \%$ with $20 \alpha$-dihydroprogesterone, $5 \cdot 5 \%$ with desoxycorticosterone, $0.2 \%$ with 17 -hydroxyprogesterone and $\sim 0.01 \%$ with other steroids); a rabbit antiserum to $17-\mathrm{OH}-\mathrm{P} 3-\mathrm{CMO}-\mathrm{BSA}$ (which cross-reacts about $5.6 \%$ with progesterone, $0.2 \%$ with $14 \alpha$-hydroxyprogesterone and $\sim 0.01 \%$ with other steroids). The diluted antiserum used was 1:2000 for progesterone and 1:5000 for 17-hydroxyprogesterone. The percentage recovery of the labelled steroids added was $70 \pm 3 \%$ for progesterone and $68 \cdot 1 \pm 2 \cdot 5 \%$ for 17 -hydroxyprogesterone. Assay sensitivities were $10 \mathrm{pg} /$ tube for progesterone and $18 \mathrm{pg} /$ tube for 17 -hydroxyprogesterone. The water blank was $15 \mathrm{pg} /$ tube for progesterone and $8.3 \mathrm{pg} /$ tube for 17-hydroxyprogesterone. The intra-assay coefficients of variation were $7 \%$ for progesterone and $10 \%$ for 17 -hydroxyprogesterone; the interassay coefficients were $8 \cdot 5 \%$ and $13 \%$ respectively.

RIA of oestradiol. Oestradiol concentrations in plasma were determined by RIA after column chromatography on Sephadex LH-20 at room temperature $(20 \mu$ l plasma), as described previously (Verdonck \& Vermeulen, 1974), utilizing rabbit antiserum to oestradiol-17 $\beta$-6-CMO-BSA (which cross-reacts about $21.9 \%$ with $17 \beta$-oestradiol 3-methyl ester, $6 \%$ with oestrone, $3.8 \%$ with oestrone 3 -methyl ester, $0.2 \%$ with oestriol and $\sim 0.01 \%$ with other steroids). The dilution of antiserum used was 1:4000. The percentage recovery of the labelled steroid added was $64 \cdot 3 \pm 7 \cdot 8 \%$. The sensitivity of the assay was $10 \mathrm{pg} /$ tube. The water blank was $10 \mathrm{pg} /$ tube. The intra- and inter-assay coefficients of variation were, respectively, 12 and $16 \%$.

Statistical analysis. Statistical analysis was performed by a non-parametric test, the Wilcoxon rank sum test (White, 1952).

\section{Results}

The annual pattern of spermatogenesis and of epididymal development, assessed by histological examination of testis and epididymides, was consistent in the timing of the various phases previously reported for the same species (Angelini et al., 1976). There was no apparent correlation between testicular weight and body weight in the size range observed during the different periods of the reproductive cycle. The testicular/body weight ratio achieved the maximal value soon after the emergence from semihibernation contemporaneously with the return of spermatogenesis and development of sexual characters (epididymis) (Angelini \& Ghiara 1984) (Table 1). In the same period, testosterone achieved a peak level with a mean value of $174.2 \mathrm{ng} / \mathrm{ml}$. After the mating period there was a sharp fall in testosterone plasma values until the next January (Fig. 1). The dihydrotestosterone values paralleled those of circulating testosterone.

Table 1. Changes in the testis, body and relative testicular weight in Podarcis s. sicula during the annual cycle

\begin{tabular}{lcccc}
\hline Month & No. & $\begin{array}{c}\text { Body weight } \\
(\mathrm{g})\end{array}$ & $\begin{array}{c}\text { Wt of testes } \\
(\mathrm{mg})\end{array}$ & $\begin{array}{c}\text { Relative testis wt } \\
(\mathrm{mg} / \mathrm{g} \text { body } w)\end{array}$ \\
\hline Jan. & 7 & $7.64 \pm 0.62$ & $30.3 \pm 2.89$ & $3.89 \pm 0.18$ \\
Feb. & 7 & $8.36 \pm 0.79$ & $41.5 \pm 4.18$ & $4.94 \pm 0.27^{\mathrm{c}}$ \\
Mar. & 7 & $11.32 \pm 0.71$ & $43.5 \pm 3.2$ & $3.8 \pm 0.14$ \\
Apr. & 8 & $9.03 \pm 0.52$ & $36.6 \pm 4.45$ & $3.95 \pm 0.3$ \\
May & 10 & $10.6 \pm 0.62$ & $40.6 \pm 3.5$ & $3.82 \pm 0.24$ \\
June & 9 & $7.73 \pm 0.36$ & $20.5 \pm 2.67^{\mathrm{d}}$ & $2.65 \pm 0.31^{\mathrm{b}}$ \\
July & 8 & $11.12 \pm 0.73$ & $22.14 \pm 4.5$ & $1.99 \pm 0.42$ \\
Sep. & 10 & $12.05 \pm 0.32$ & $13.32 \pm 1 \cdot 13$ & $1.11 \pm 0.07^{\mathrm{a}}$ \\
Oct. & 10 & $11.24 \pm 0.4$ & $37 \pm 1.89$ & $3.29 \pm 0.13$ \\
Nov. & 8 & $10.03 \pm 0.65$ & $28.4 \pm 3.54^{\mathrm{d}}$ & $2.83 \pm 0$ \\
Dec. & 6 & $6.19 \pm 0.51^{\mathrm{a}}$ & $19.27 \pm 3.19$ & $2.94 \pm 0.26$ \\
\hline
\end{tabular}

Values are mean \pm s.e.m.

${ }^{\mathrm{a}} P<0.05 ;{ }^{\mathrm{b}} P<0.02 ;{ }^{\mathrm{c}} P<0.002 ;{ }^{\mathrm{d}} P<0.001$ compared with value for the preceding month. 


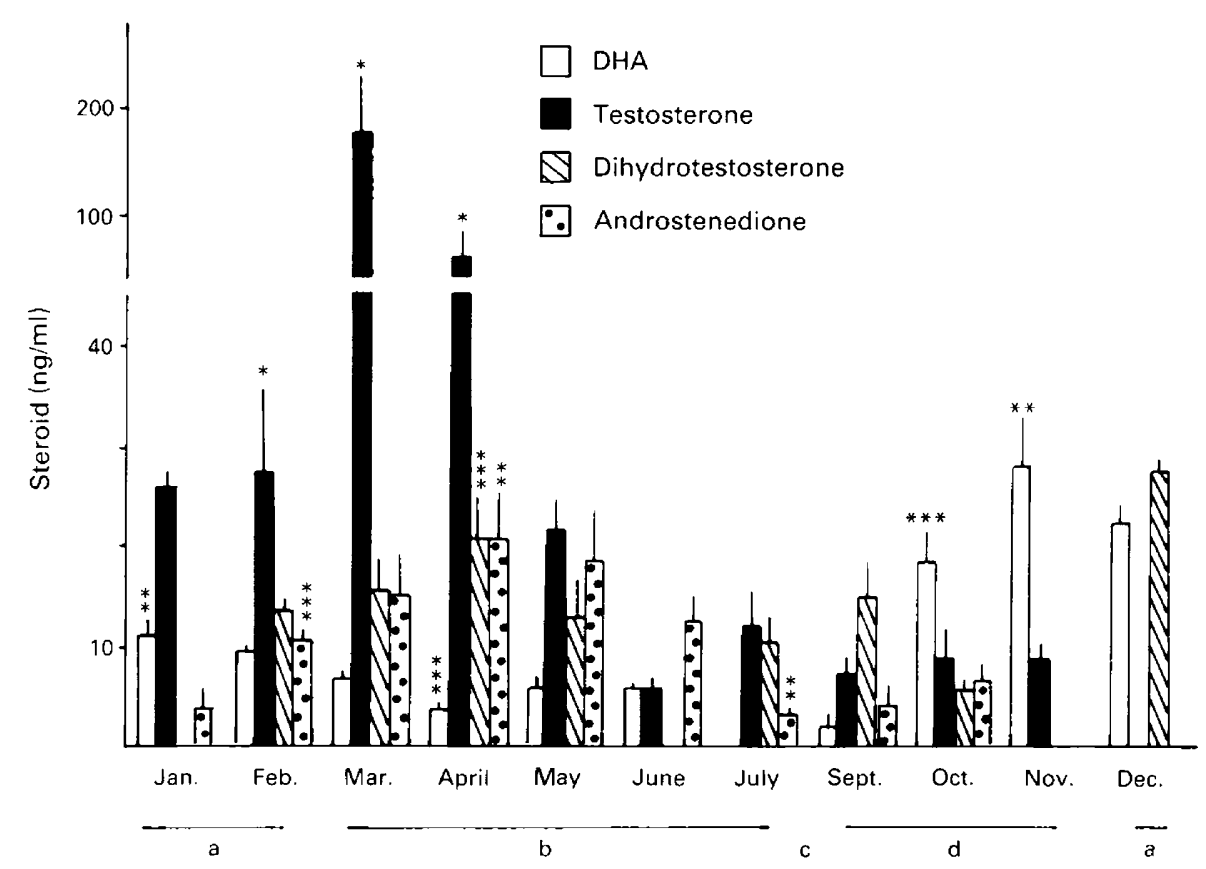

Fig. 1. Plasma concentrations of androgens during the reproductive cycle of male lizards. a, Winter arrest; $b$, full spermatogenesis spermiation and development of secondary sex characters; $c$, regression of gonadal and secondary sex characters; $d$, abortive spermatogenesis, no spermiation, no development of secondary sex characters. Values are mean \pm s.e.m. ${ }^{*} P<0.05 ;{ }^{* *} P<0.02 ;{ }^{* * *} P<0.01$ compared with value for preceding month.

Androstenedione showed a peak level in April, slightly shifted with respect to that of testosterone; values were relatively high until June when they were greater than those of testosterone. Dehydroepiandrosterone showed a different pattern, with lower levels during the breeding period. After orchidectomy there was a decrease in dehydroepiandrosterone only in the late autumn (December) (Fig. 2). In castrated lizards, testosterone, to a great extent, androstenedione and $5 \alpha$-dihydrotestosterone decreased markedly in the three periods chosen for our investigation. After castration in March, however, plasma concentrations of testosterone and androstenedione persisted more conspicuously than in the other two periods (Fig. 2).

In intact animals progesterone increased from March and in July its peak value $(8.56 \mathrm{ng} / \mathrm{ml})$, was concomitant with that of oestradiol when refractoriness set in (Fig. 3). The 17-hydroxyprogesterone concentrations increased in late autumn and early winter (Fig. 3).

\section{Discussion}

The plasma hormone profile in the lizard, Podarcis s. sicula, reveals that testosterone achieves a peak level in the early spring. This peak, although with a large range of variations, is substantially higher than that reported for other reptilian species $(7.4 \mathrm{ng} / \mathrm{ml}$ in Chrysemys picta, $32.5 \mathrm{ng} 17$ hydroxysteroids $/ \mathrm{ml}$ in Tiliqua rugosa, $22.4 \mathrm{ng} / \mathrm{ml}$ in Uromastyx hardwicki, $6.2 \mathrm{ng} / \mathrm{ml}$ in Naja naja (Callard et al., 1976; Arslan et al., 1978; Bourne \& Seamark, 1978; Bona Gallo et al., 1980), but lower than that observed in the viviparous lizard, Lacerta vivipara $(445 \cdot 2 \mathrm{ng} / \mathrm{ml}$ ) (Courty \& Dufaure, 1979, 1980).

During the reproductive cycle, in contrast to findings for other species, testosterone was not always the predominant androgen in Podarcis: the androstenedione/testosterone ratio ranged from 


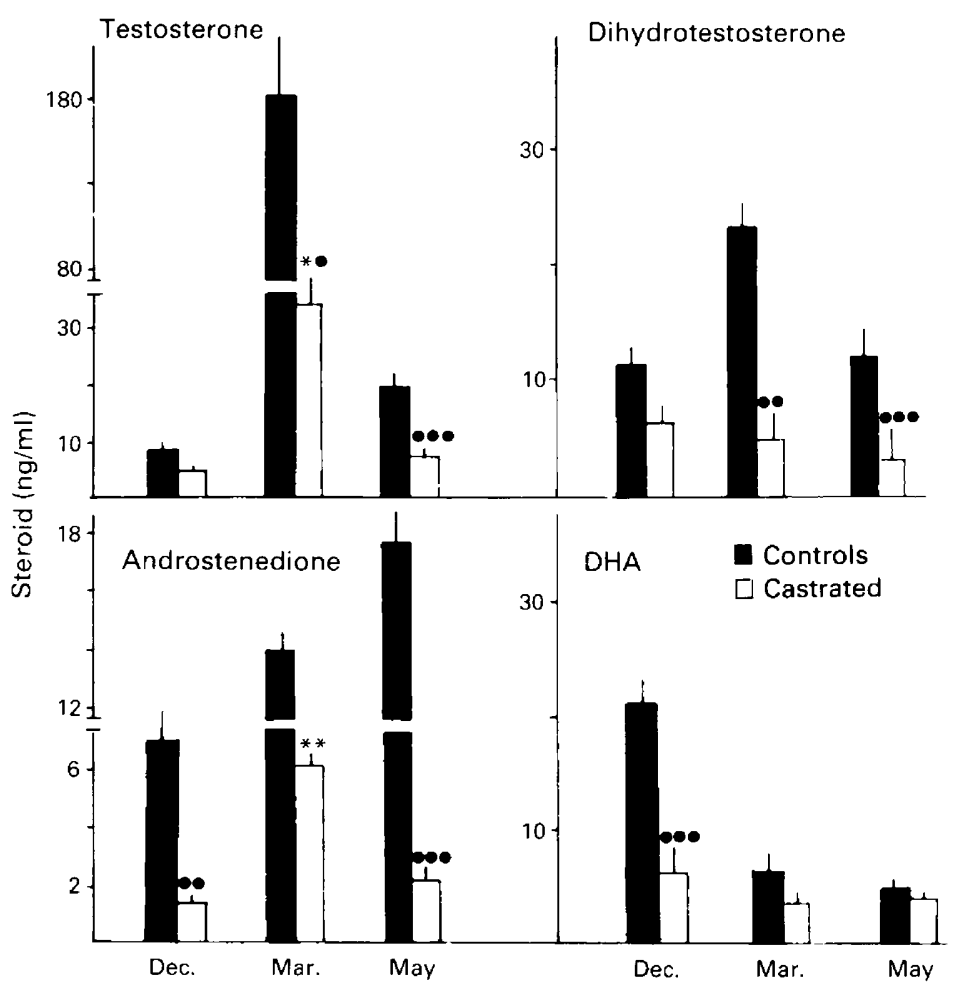

Fig. 2. Circulating concentrations of androgens before and after castration of male lizards in December, March and May. Values are mean \pm s.e.m. ${ }^{*} P<0.05 ;{ }^{* *} P<0.01$ compared with castrated males at other times; $\bullet P<0.05 ; \bullet \bullet P<0.02 ; \bullet \bullet \bullet P<0.01$ compared with control values.

0.14 to $2 \cdot 424$, while the dehydroepiandrosterone/testosterone ratio ranged fom 0.08 to $2 \cdot 04$. The dihydrotestosterone values obtained during the annual cycle parallel circulating concentrations of testosterone. In mammals, plasma values of dihydrotestosterone originate prevalently from peripheral conversion from testosterone itself (Vermeulen, 1973). The marked decrease of testosterone, 3 weeks after castration, demonstrates that the main testicular androgen produced by the testis of Podarcis s. sicula is testosterone. This finding is consistent with observations of other reptilian species (see Licht, 1984; Lofts, 1987, for review; Arslan et al., 1978; Hews \& Kime, 1978; Bourne et al., 1986; Callard \& Kleis, 1987). However, the effect of castration on circulating levels of androgens depends on the period of the year. The lizards castrated during the time of seasonal reactivation of the gonads (March) in fact had conspicuous amounts of testosterone and androstenedione in the plasma. Although seasonal differences in hormone clearance rates could explain the latter finding, an adrenal contribution to androgen circulating levels cannot be ruled out. In mammals it is well documented that testosterone and androstenedione are secreted by the adrenals (Bardin \& Peterson, 1967). It has been reported that both steroids increase in the plasma during the period after castration (Andò et al., 1986, 1988b). Gonadal steroid administration can modulate adrenal androgen secretion in castrated animals (Andò et al., 1988b, 1989). If a similar interrenalgonadal interaction is inferred in reptiles, we could suppose a different response of the adrenal secretion according to the dramatic changes in sex steroid concentrations during the various periods of the reproductive cycle.

Orchidectomy induces a lowering of dehydroepiandrosterone plasma values only in December. This could indicate that testicular secretions contribute to the plasma concentrations of this steroid 


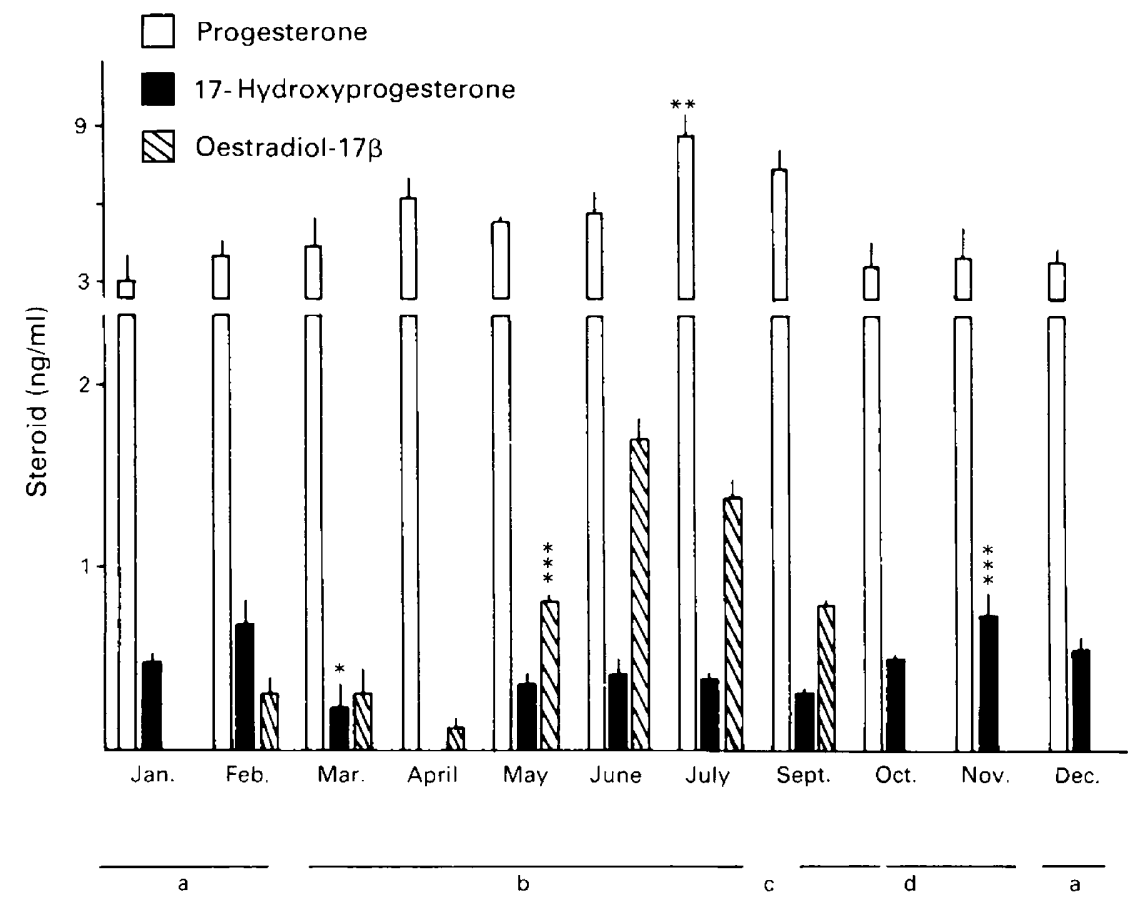

Fig. 3. Plasma concentrations of progesterone ( $\square$ ), 17-hydroxyprogesterone ( $\boldsymbol{\square}$ ) and oestradiol-17ß $(\mathbb{Q})$ during the reproductive cycle of male lizards. a, Winter arrest; b, full spermatogenesis, spermiation and development of secondary sex characters; c, regression of gonadal and secondary sex characters; $d$, abortive spermatogenesis, no spermiation, no development of secondary sex characters. Values are mean \pm s.e.m. ${ }^{*} P<0.05 ;{ }^{* *} P<0.02$; ${ }^{* * *} P<0.01$ compared with value for preceding month.

which is mainly secreted by adrenals. Large amounts of dihydroepiandrosterone have been found in testicular extracts of Podarcis s. sicula (454 pg/mg fresh tissue) (Lupo di Prisco et al., 1967).

The above results suggest that, in the winter period, the $5 \alpha$ metabolic pathway is mainly active for testicular androgen biosynthesis. This suggestion is supported by previous data concerning the annual variations of testicular $\Delta 5-3 \beta$-hydroxysteroid dehydrogenase in Lacerta vivipara; using histoenzymological and morphological criteria, the enzyme activity was reported to be lower during the post-reproductive period (Courty \& Dufaure, 1979, 1980). This enzymic cycle resembles those of closely related species (Measure, 1968; Licht et al., 1969; Morat, 1969; Licht, 1984).

Androstenedione has been reported to be a critical intermediate between testosterone and oestrogen formation (Pierrepoint et al., 1966; Payne et al., 1976). Therefore, the increased androstenedione concentrations found in Podarcis s. sicula could contribute to the increased oestradiol values in the post-reproductive phase, following the same pathway which usually operates in mammalian tissue (van der Molen \& Rommerts, 1981; Martini, 1982). Oestradiol has been detected in the plasma of males of several lower vertebrate species, including the water frog, Rana esculenta (Polzonetti-Magni et al., 1984), and the lizards, Podarcis s. sicula (Ciarcia et al., 1986) and Chalcides ocellatus (Angelini et al., 1987). In these species the oestradiol plasma concentration progressively rises in spring as breeding proceeds and usually peaks in summer when reproduction is over. It is well documented that oestradiol exerts an antigonadal effect in Podarcis s. sicula males. If injected into mature males it induces a dramatic regression of interstitial testicular tissue, an impairment of spermatogenesis and epididymal atrophy (Botte \& Del Rio, 1967). This steroid could, therefore, exert a systemic negative feed-back on the hypothalamic-pituitary axis, resulting in an inhibitory effect on gonadotrophin secretion (Angelini et al., 1986) and/or a local action on endocrine tissues 
by inhibitory regulation of some enzymes involved in steroid biosynthesis (Botte \& Del Rio, 1967; Oshima et al., 1967; Mulder et al., 1974). Indeed, the progressive increase of progesterone, as well as of the progesterone/17-hydroxyprogesterone ratio, simultaneously with that of oestradiol in the plasma probably reflects some impairment of $17 \alpha$-hydroxylase activity in endocrine tissues (Samuels et al., 1967, 1969). The present observations support the suggestion that oestradiol could play an important role in the cessation of breeding as well as on the post-reproductive refractoriness of male Podarcis s. sicula.

\section{References}

Andò, S., Giacchetto, C., Tagarelli, A. \& Brancati, C. (1984) The evaluation of testosterone and its precursors in spermatic venous blood of normal men and varicocele subjects. In 2nd Symposium of the Analysis of Steroids, pp. 165-179. Ed. S. Gorog. Akademia Kiodo, Budapest.

Andò, S., Giacchetto, C., Canonaco, M., Aquila, S., Valenti, A., Piro, A. \& Dessi-Fulgheri, F. (1986) Effects of castration on androstenedione, testosterone and dihydrotestosterone plasma leveis in adult male rats. Horm. Res. 23, 122-127.

Andò, S., Aquila, S., Beraldi, E., Canonaco, M., Panno, M.L., Valenti, A. \& Dessi-Fulgheri, F. (1988a) Physiological changes in androgen plasma levels with elapsing of time from castration in adult male rats. Horm. Metab. Res. 20, 96-99.

Andò, S., Canonaco, M., Beraldi, E., Valenti, A., Maggiolini, M., Piro, A., Tavolaro, R. \& DessiFulgheri, F. (1988b) The evaluation of androgen circulating levels following castration in adult male rats. Exp. clin. Endocrinol. 91, 311-318.

Andò, S., Canonaco, M., Valenti, A., Aquila, S., Tavolaro, R., Maggiolini, M., Panno, M.L. \& Dessi-Fulgheri, F. (1989) The in vitro conversion of $3 \mathrm{H}$ androstenedione to testosterone and dihydrotestosterone in the adrenal gland of castrated male rat: influence of gonadal steroid administration. Exp. clin. Endocrinol. 93, 83-89.

Angelini, F. \& Ghiara, G. (1984) Reproductive modes and strategies in vertebrate evolution. Boll. Zool. 51, 121-203.

Angelini, F., Picariello, O. \& Botte, V. (1976) Influence of photoperiod and temperature on the testicular activity of the lizard Lacerta s. sicula. Raf. Boll. Zool. 43, $111-123$.

Angelini, F., Ciarcia, G., Picariello, O., Botte, V.\& Pagano, M. (1986) Sex steroids and post-reproductive refractoriness in the lizard Podarcis Sicula. Boll. Zool. 53, $59-62$.

Angelini, F., Ciarcia, G., Zerani, M., Polzonetti, A.\& Botte, V. (1987) Sex hormones during the annual cycle in two lizards Podarcis s. sicula (oviparous) and Chalcides ocellatus (viviparous). Gen. comp. Endocrinol. 66, $24-32$.

Arslan, M., Lobo, J., Zaidi, A.A., Jalali, S. \& Quasi, N.H. (1978) Annual androgen rhythm in the spinytailed lizard Uromastix hardwicki. Gen. comp. Endocrinol. 36, 16-22.

Bardin, C.W. \& Peterson, R.E. (1967) Studies of androgen production by the rat: testosterone and androstenedione content of blood. Endocrinology 80, 38-44.

Bona Gallo, A., Licht, P., MacKenzie, D.S. \& Lofts, B. ( 1980$)$ Annual cycles in levels of pituitary and plasma gonadotropin, gonadal steroids, and thyroid activity in the Chinese Cobra (Naja naja). Gen. comp. Endocrinol. 42, 477-493.

Botte, V.\& Del Rio, G. (1967) Effect of estradiol-17 $\beta$ on the distribution of $3 \beta$-hydroxysteroid dehydrogenase in the testes of Rana esculenta and Lacerta sicula. Gen. comp. Endocrinol. 9, 110-116.

Bourne, A.R. \& Seamark, R.F. (1978) Seasonal variation in steroid biosynthesis by the testis of the lizard Tiliqua Rugosa. Comp. Biochem. Physiol. 59B, 363-367.

Bourne, A.R., Taylor, J.L. \& Watson, T.G. (1986) Annual cycle of plasma testicular androgens in the lizard Tiliqua(Tchydosan) rugosa. Gen.comp. Endocrinol.61, 278-286

Bradshaw, S.D., Owen, F.J. \& Saint-Girons, H. (1988) Seasonal changes in plasma sex steroid levels in the male tuatara Sphenodon punctatus from Stephens Island, New Zealand. Gen. comp. Endocrinol. 70, $460-465$.

Callard, I.P., Callard, G.V., Lance, V. \& Eccles, S. (1976) Seasonal changes in testicular structure and function and the effects of gonadotropins in the fresh water turtle Chrysemys picta. Gen. comp. Endocrinol. 30, 347-356.

Callard, I.P. \& Kleis, S.M. (1987) Reproduction. In Fundamentals of Comparative Vertebrate Endocrinology, pp. 187-205. Eds I. Chester-Jones, P. M. Ingleton \& J. G. Phillips. Plenum Press, New York.

Chester-Jones, I. (1987) Structure of the adrenal and interrenal glands. In Fundamentals of Comparative Vertebrate Endocrinology, pp. 95-120. Eds I. Chester-Jones, P. M. Ingleton \& J. G. Phillips. Plenum Press, New York.

Ciarcia, G., Angelini, F., Polzonetti, A., Zeroni, M. \& Botte, V. (1986) Hormones and reproduction in the lizard Podarcis s. sicula Raf. In Endocrine Regulations and Adaptive Mechanisms to the Environments, pp. 95-100. Eds I. Assenmacher \& J. Boissin. CNRS, Paris.

Courty, Y. \& Dufaure, J.P. (1979) Levels of testosterone in the plasma and testis of the viviparous lizard Lacerta vivipara Jacquin during the annual cycle. Gen. comp. Endocrinol. 39, 336-342.

Courty, Y. \& Dufaure, J.P. (1980) Levels of testosterone, Dihydrotestosterone and Androstenedione in the plasma and testis of a lizard Lacerta vivipara Jacquin during the annual cycle. Gen. comp. Endocrinol. 42, $325-333$.

Hews, E.A. \& Kime, D.E. (1978) Testicular steroid biosynthesis by the green lizard Lacerta viridis. Gen. comp. Endocrinol. 35, 432-435.

Kime, D.E. (1987) The steroids. In Fundamentals of Comparative Vertebrate Endocrinology, pp. 3-56. 
Eds I. Chester-Jones, P. M. Ingleton \& J. G. Phillips. Plenum Press, New York.

Licht, P. (1984) Reptiles. In Marshall's Physiology of Reproduction, 4th edn, Vol. 1, pp. 206-282. Ed. G. E. Lamming. Churchill Livingstone, Edinburgh.

Licht, P., Hoyer, H.E. \& Van Oordt, G.P.V.J. (1969) Influence of photoperiod and temperature on testicular recrudescence and body growth in the lizard Lacerta sicula and Lacerta muralis. J. Zool., Lond. 157, 469-501.

Lofts, B. (1987) Testicular function. In Hormones and Reproduction in Fishes, Amphibians and Reptiles, pp. 283-325. Eds D. O. Norris \& R. E. Jones. Plenum Press, New York.

Lupo di Prisco, C., Chieffi, G. \& Del Rio G. (1967) Identification of steroid hormones from Lacerta s. sicula testes. Experientia 23, 173-74.

Mahmoud, I.Y., Gyrus, R.V., Bennet, T.M., Woller, J. \& Montag, D.M. (1985) Ultrastructural changes in testes of the Snapping Turtle Chelidra serpentina in retation to plasma testosterone, $3 \beta$-hydroxysteroid dehydrogenase and cholesterol. Gen. comp. Endocrinol. 57, 454-464.

Martini, L. (1982) The 5 $\alpha$-reduction of testosterone in the neuroendocrine structures. Biochemical and physiological implications. Endocrinol. Rev. 31, 1-25.

Measure, M. (1968) Mise en evidence d'une variation annuelle de l'activitè $53 \beta$-hydroxysteroide dehydrogenasique dans le testicule de lezard vivipare Lacerta vivipara. C.r. Séanc. Soc. Biol. 162, 422-425.

Morat, M. (1969) Contribution a l'étude de l'activité $\Delta 53 \beta$-hydroxysteroide deshydrogenasique chez quelques Reptiles du Massif Central. Ann. Stat. Biol. Besse Chandesse 4, 1-74.

Mulder, E., Van Beurden-Lamers, W.M.O., DeBoer, W., Brinkman, A.O. \& Van der Molen, H.J. (1974) Testicular oestradiol receptors in the rat. In Hormone Binding and Target Cell Activation in the Testis, pp. 343-355. Eds M. L. Dufau \& A. R. Means. Plenum, New York.

Oshima, H., Wakabayashi, K. \& Tamaoki, B. (1967) The effect of synthetic estrogen upon the biosynthesis in vitro of androgen and luteinizing hormone in the rat. Biochim. Biophys. Acta 137, 356-364.
Payne, A.H., Kelch, R.P., Musich, S.S. \& Halpern, M.E. (1976) Intratesticular site of aromatization in the human. J. clin. Endocr. Metab. 42, 1081-1087.

Pierrepoint, C.G., Griffiths, K., Grant, J.K. \& Stewart, J.S.S. (1966) Neutral steroid sulphation and oestrogen biosynthesis by a feminizing Leydig cell tumour of the testis. J. Endocr. 35, 409-417.

Polzonetti-Magni, A., Botte, V., Bellini-Cardellini, L., Gobetti, A. \& Crosto, A. (1984) Plasma sex hormones and post-reproductive period in the green frog Rana esculenta complex. Gen. comp. Endocrinol. 54, 372-377.

Rivarola, M.A., Snipes, C.A. \& Migeon, C.J. (1968) Concentration of androgens in systemic plasma of rats, guinea pigs, salamanders and pigeons. Endocrinology 82, $115-121$.

Samuels, L.T., Uchikawa, T. \& Huseby, R.A. (1967) Direct and indirect effects of oestrogen on the enzymes of the testis. Ciba Fnd. Colloq. Endocrinol. 16, $211-232$.

Samuels, L.T., Uchikawa, T., Zain-el-abedim, M. \& Huseby, R.A. (1969) Effect of diethylstilbestrol on enzymes of cryptorchid mouse testes of balb/c mice. Endocrinology 85, 96-103.

Tam, W.H., Phillips, J.G. \& Lofts, B. (1969) Seasonal changes in the in vitro production of testicular androgens by the cobra, Naja naja. Gen. comp. Endocrinol. 13, 117-125.

van der Molen, H.J. \& Rommerts, F.F.G. (1981) Testicular steroidogenesis. In The Testis, pp. 213-238. Eds H. Burger \& D. de Kretser. Raven Press. New York.

Verdonck, L. \& Vermeulen, A. (1974) Comparison of quick methods for the estimation of oestradiol in plasma by radioimmunoassay. $J$. Steroid Biochem. 5 , $471-479$.

Vermeulen, A (1973) The metabolic clearance rate and the metabolism of testosterone. In Endocrine Function of the Human Testis, vol. 1, pp. 181-193. Eds V. H. T. James, M. Serio \& L. Martini. Academic Press, New York.

White, C. (1952) The use of ranges in a test of significance for comparing two treatments. Biometrics $\mathbf{8}$, 33-34.

Received 11 December 1989 